\title{
IMPLEMENTASI METODE QUALITY FUNCTION DEPLOYMENT DAN METODE SERVQUAL DIMENSI KEPARIWISATAAN GUNA PERBAIKAN KUALITAS PARIWISATA PANTAI KEBUMEN (Studi Kasus pada Pantai Logending, Pantai Manganti, Pantai Suwuk, Pantai Petahanan, dan Pantai Brencong)
}

\author{
Kabul Trifiyanto, Ika Susilowati \\ STIE Putra Bangsa Kebumen \\ e-mail: kabul.trifiyanto@gmail.com
}

\begin{abstract}
Kebumen tourism is dominated by south coast destination objects with combat routes ranging from half to two hours drive from the city center. Since 2015 tourist visits have increased, but on average only $14 \%$. This is not comparable with the budget issued by the government to date which focuses on tourism infrastructure and the opening of new objects, especially coastal areas. According to preliminary studies the cause is because of visitor dissatisfaction with the quality of services provided, especially coastal tourism. So as to provide recommendations for improvements in tourism services in this study, the quality function deployment (QFD) method is based on servqual evaluation specifically for tourism dimensions. There are 43 variables used to define the quality of service dimensions of tourism for visitors. By using additional kano models, 12 critical variables were obtained. Then the critical variable produces 16 technical responses through the house of quality method for later as a recommendation for improvement. With the priority of repairs are; making tourist management SOPs, adding cleaners, and adding a viewing post/spot.
\end{abstract}

Keywords: quality function deployment, servqual, tourism, kano

\section{PENDAHULUAN}

Pariwisata menjadi prioritas nasional dalam RPJM 2015-2019. Di akhir RPJM 2019 periode kepemimpinan Presiden Joko Widodo menargetkan wisatawan asing berkunjung sejumlah 20 juta sedangkan wisatawan nusantara atau pengunjung dalam negeri sebanyak 275 juta orang. Nilai devisa yang ditargetkan dari sektor ini adalah 260 triliun. Pada tahun 2017 sektor pariwisata menjadi program prioritas yaitu program pembangunan wisata "Wonderful Indonesia”. Pariwisata merupakan salah satu dari lima sektor pembangunan 2017, yaitu pangan, energi, maritim, pariwisata, kawasan industri, dan kawasan ekonomi khusus (KEK) sesuai RKP 2017 (Setkab, 2017).
Menteri Pariwisata aktif Arief menyatakan sektor wisata memiliki keunggulan ketimbang sektor lainnya, yakni lebih cepat mendatangkan devisa dan menciptakan lapangan kerja baru. Selain itu, biaya untuk pengembangan sektor pariwisata juga jauh lebih murah dibanding sektor lain. Oleh karena itu, sektor wisata ke depanya akan menjadi core economy bagi Indonesia karena merupakan komoditas yang paling sustainable, paling menyentuh ke level ekonomi dengan share economy dan performance setiap tahunnya menanjak (Tempo, 2017).

Tabel 1 Kunjungan Wisatawan Asing ke Indonesia

\begin{tabular}{|l|l|l|l|l|}
\hline & $\mathbf{2 0 1 2}$ & $\mathbf{2 0 1 3}$ & $\mathbf{2 0 1 4}$ & $\mathbf{2 0 1 5}$ \\
\hline $\begin{array}{l}\text { Wisatawan asing } \\
\text { (dlm Juta) }\end{array}$ & 8.04 & 8.80 & 9.44 & 9.73 \\
\hline
\end{tabular}

Sumber: www.Indonesia-nvestment.com 
Tabel 2 Kondisi Industri Pariwisata Indonesia

\begin{tabular}{|l|c|c|c|c|}
\hline & 2016 & 2017 & 2018 & 2019 \\
\hline $\begin{array}{l}\text { Kontribusi terhadap } \\
\text { PDB (\%) }\end{array}$ & 11 & 13 & 14 & 15 \\
\hline $\begin{array}{l}\text { Penerimaan devisa } \\
\text { (triliun) }\end{array}$ & 172,8 & 182,0 & 223,0 & 275,0 \\
\hline $\begin{array}{l}\text { Penyerapan tenaga } \\
\text { kerja (juta orang) }\end{array}$ & 11,7 & 12,4 & 12,7 & 13 \\
\hline Kunjungan wisman & 12 & 15 & 17 & 20 \\
\hline Kunjungan wisnus & 260 & 265 & 270 & 275 \\
\hline
\end{tabular}

Sejalan dengan perkembangan industri pariwisata yang menjadi salah satu prioritas pembangunan nasional. Kebumen adalah salah satu kota di Jawa Tengah dengan beberapa destinasi wisata yang cukup kaya. Kebumen tidak mau kalah dengan kondisi nasional yang cukup baik di sektor pariwisata. Hal ini terlihat pada visi bupati periode 2015-2019, yaitu mengembangkan kemandirian perekonomian darah yang bertumpu pada pengembangan potensi lokal unggulan yang berdaya saing dengan salah satunya sektor pariwisata (Kebumenkab, 2017).

Dari pengembangan objek wisata paling banyak adalah pantai. Kunjungan wisata selama tahun 2015 sebesar 1.250.859 orang pengunjung, meningkat $14,8 \%$ dibanding tahun sebelumnya yang berjumlah 1.089 .553 orang. Dari jumlah pengunjung tersebut ada enam wisatawan mancanegara.

Jumlah wisatawan nusantara atau domestik pada tahun 2015 hanya 0,38\% dibandingkan dengan jumlah wisatawan nusantara secara nasional. Hal ini mengindikasikan masih besar kesempatan untuk meningkatkan jumlah wisatawan nusantara. Selain itu, wisatawan mancanegara masih belum diperhatikan terlihat hanya enam orang wisatawan dari satu juta wisatawan yang mendatangi objek wisata di Kebumen. Apabila dilihat dari total wisatawan mancanegara secara nasional pada tahun yang sama adalah 9,73 juta orang.
Ada beberapa tantangan yang dihadapi pada sektor pariwisata sehingga menjadi perhatian khusus. Pada survei terkait tingkat kepuasan pengunjung yang dibuat oleh penulis khusus objek wisata Pantai di Kebumen. Ada tiga variabel yang diteliti yaitu, pertama kepuasan pada pelayanan petugas yang menunjukkan $53 \%$ pengunjung tidak puas terhadap kualitas pelayanan petugas. Kemudian variabel kedua suasana lokasi objek wisata pantai menunjukkan nilai 12,5\% pengunjung tidak puas. Variabel terakhir adalah fasilitas pendukung di objek wisata pantai menunjukkan 50\% pengunjung tidak puas terhadap kualitas fasilitas pendukung.

Ketidakpuasan pengunjung menunjukkan adanya gap antara pelayanan yang diberikan oleh pihak pengelola objek wisata dengan harapan dari pengunjung. Apalagi dengan adanya media internet yang memberikan informasi yang cepat sehingga begitu mudahnya pengunjung membandingkan kualitas layanan yang diberikan dengan objek wisata di lokasi lain atau kota lain. Dari hasil wawancara dengan beberapa pengunjung disimpulkan masih terdapat beberapa kekurangan terkait sarana dan prasarana penunjang objek wisata maupun terkait pelayanan. Dilihat mulai dari akses yang cukup sulit dan jauh dari pusat kota, fasilitas pendukung di lokasi yang jauh dari wahana kemudian adanya beberapa tempat yang minim dengan petugas resmi, kebersihan masih kurang.

Standardisasi kualitas layanan dimensi pariwisata khususnya objek wisata pantai menjadi penting apabila hendak mewujudkan visi Pemerintah Kabupaten Kebumen. Peningkatan kualitas objek wisata diharapkan dapat memberikan kepuasan yang pada hasil akhirnya akan memberikan kontribusi PDP daerah. Namun mengingat APBD yang terbatas maka biaya untuk peningkatan kualitas jasa sektor wisata menjadi terbatas 
Kabul Trifiyanto, Ika Susilowati, Implementasi Metode Quality Function Deployment dan Metode Servqual Dimensi Kepariwisataan Guna Perbaikan Kualitas Pariwisata Pantai Kebumen

maka perlu adanya strategi efisiensi biaya untuk menentukan prioritas perbaikan yang memberikan dampak yang besar.

Berdasarkan uraian di atas, studi ini ingin mengkaji beberapa hal berikut. (1) Variabel apa saja yang berpengaruh terhadap kualitas pelayanan jasa tempat pariwisata pantai di Kebumen. (2) Bagaimana pengaruh persepsi dan ekspektasi pengunjung terhadap kinerja kualitas pelayanan jasa yang diberikan tempat pariwisata pantai di Kebumen. (3) Atribut-atribut dan dimensi kualitas pelayanan jasa manakah yang harus segera diperbaiki. (4) Apa saja yang menjadi kebutuhan pengunjung (consumer needs) dalam pemilihan objek wisata khususnya pantai di Kebumen.

\section{KAJIAN LITERATUR}

\section{Pariwisata}

Pariwisata adalah rangkaian aktivitas, dan penyediaan layanan baik untuk kebutuhan atraksi wisata, transportasi akomodasi, dan layanan lain yang ditujukan untuk memenuhi kebutuhan perjalanan seseorang atau sekelompok orang. Perjalanan yang dilakukan hanya untuk sementara waktu saja meninggalkan tempat tinggalnya dengan maksud beristirahat, berbisnis, atau untuk maksud lain (Sugiama, 2011).

Suwantoro (2004) menjelaskan beberapa ciri produk wisata adalah sebagai berikut.

1. Hasil atau produk wisata tidak dapat dipindahkan sehingga dalam penjualannya produk tidak dibawa ke konsumen (wisatawan) sebaliknya konsumen (wisatawan) harus dibawa ke tempat produk dihasilkan.

2. 'Produksi dan konsumsi terjadi pada tempat dan saat yang sama, tanpa adanya konsumen (wisatawan) membeli produk wisata maka tidak akan terjadi produksi.
3. Produk wisata tidak menggunakan ukuran standar fisik, melainkan menggunakan standar pelayanan dengan kriteria tertentu.

4. Konsumen (wisatawan) tidak bisa mencoba contoh produk wisata sebelumnya atau tidak dapat mengetahui atau menguji sebelum digunakan.

5. Hasil atau produk wisata banyak tergantung pada tenaga manusia dan sedikit menggunakan tenaga mesin.

Produk wisata merupakan usaha yang mengandung risiko.

\section{Kepuasan Pengunjung}

Produk yang dihasilkan oleh suatu organisasi/perusahaan tidak akan berguna apabila tidak menghasilkan kepuasan bagi konsumen (pengunjung) serta mempertahankannya. Kotler (2004) mendefinisikan kepuasan sebagai perasaan senang atau kecewa yang berasal dari perbandingan antara persepsi (perception) terhadap kinerja/ hasil (performance) suatu produk dengan harapan (expectation). Bila kinerja produk dari pengalaman dari pengalaman mengonsumsi berada di bawah harapan, kondisi ini menunjukkan hal tidak puas (dissatisfied). Bila sama maka menunjukkan puas (satisfied). Apabila hasilnya di atas maka bisa dikatakan sangat puas (bighly satisfied).

\section{Kualitas Jasa Pariwisata}

Kualitas jasa menurut Parasuraman et al. (1998) terdapat batasan pengertian yaitu kualitas pelayanan merupakan dasar bagi pemasaran jasa, karena inti produk yang dipasarkan adalah suatu kinerja (yang berkualitas), dan kinerjalah yang dibeli oleh pelanggan sehingga kualitas jasa pelayanan merupakan dasar bagi pemasaran jasa. 
Adapun lima kesenjangan yang telah dikutip oleh Fandy Tjiptono (2011) adalah sebagai berikut. 1. Kesenjangan antara harapan konsumen dan persepsi pihak penyedia jasa. Manajemen tidak selalu dapat merasakan apa yang diinginkan oleh para pelanggan secara tepat.

2. Kesenjangan antara persepsi pihak penyedia jasa dan spesifikasi kualitas jasa. Mungkin pihak penyedia jasa mampu merasakan secara tepat apa yang diinginkan oleh para pelanggan, namun tidak menyusun suatu kinerja tertentu.

3. Kesenjangan antara spesifikasi jasa dan penyampaian jasa. Karyawan pihak penyedia jasa mungkin kurang dilatih atau bekerja melampaui batas dan tidak dapat dan tidak mau untuk memenuhi standar.

4. Kesenjangan antara penyampaian jasa dan komunikasi eksternal. Harapan konsumen dipengaruhi oleh pernyataan-pernyataan yang dibuat oleh wakil (representative) dan iklan perusahaan.

5. Kesenjangan antara jasa yang dirasakan dan jasa yang diharapkan.

Pariwisata merupakan industri jasa yang unik dibanding dengan perusahaan lainnya. Pariwisata merupakan perpaduan antara beberapa faktor sehingga mampu menjadi komoditi bisnis. Menurut Spillane dan Meidy dalam Bambang (2010), suatu objek wisata meliputi lima unsur penting yang dapat dijadikan patokan pengukuran kualitas produk yang ditawarkan kepada pengunjung/wisatawan sebagai berikut.

1. Attractions (atraksi), yaitu hal-hal yang menarik perhatian para wisatawan.

2. Facilities (fasilitas), yaitu fasilitas-fasilitas yang diperlukan.

3. Infrastructure \& transportation (infrastruktur dan transportasi), yaitu prasarana yang dimiliki atau tersedia di lingkungan pariwisata serta jasa-jasa pengangkutan menuju dan dari objek wisata.

4. Hospitality (keramahtamahan); yaitu kesediaan pihak pariwisata dalam menerima tamu.

5. Information and promotion (informasi dan promosi); yaitu informasi yang ada terkait objek wisata baik secara umum maupun disediakan oleh objek tersebut.

6. Price (harga), yaitu harga produk objek wisata.

\section{Quality Function Development}

Quality function development (QFD) adalah metode terstruktur yang digunakan dalam proses perencanaan dan pengembangan produk untuk menetapkan spesifikasi kebutuhan dan keinginan konsumen serta mengevaluasi suatu produk dalam memenuhi kebutuhan dan keinginan konsumen.

Penerapan QFD memiliki beberapa tahapan, yaitu: (1) penjaminan kualitas produk atau jasa; (2) penjabaran persyaratan konsumen melalui pendapat konsumen (angket, survei); (3) penjabaran karakteristik kebutuhan konsumen (checklist); (4) pembuatan matriks house of quality yang dimulai dengan penentuan hubungan antara kebutuhan kualitas dan karakteristik kualitas, penerapan sejumlah nilai berdasarkan sejumlah angka tertentu terhadap masing-masing karakteristik kualitas, penyatuan karakteristik kualitas ke produk, perancangan produksi, dan pengendalian kualitas.

\section{METODE PENELITIAN}

\section{Populasi dan Sampel Penelitian}

Populasi dalam penelitian ini adalah lima objek wisata pantai di Kebumen. Berdasarkan populasi tersebut maka penentuan sampel dalam penelitian ini adalah menggunakan teknik sampling non-probability sampling khususnya accidental sampling. Cara pengambilan sampel dila- 
kukan pada responden yang kebetulan ditemui atau dijumpai pada saat penelitian. Hal ini disebabkan karena pengunjung pada objek wisata tidak selalu tetap. Selain itu, dengan teknik ini akan menghemat waktu. Jumlah sampel yang diambil adalah 100 (Widiyanto, 2008). Pengambilan sampel dalam penelitian ini dilakukan pada lima objek wisata pantai di Kebumen, yaitu Logending, Manganti, Suwuk, Petahanan, dan Brencong.

\section{Identifikasi Atribut dan Penyusunan Kuesioner}

Untuk mendapatkan atribut-atribut jasa objek wisata pantai di Kebumen, dilakukan mini riset pada objek penelitian dengan cara observasi, wawancara dan kuesioner kepada responden serta studi pustaka atas dimensi kualitas layanan pariwisata yaitu atraksi (attraction), fasilitas (facilities), infrastruktur, dan transportasi (infrastructure \& transportation), keramahtamahan (hospitality), informasi dan promosi (information \& promotion), harga (price) dan tambahan atribut dari servqual yaitu keamanan (assurance). Kemudian dari atribut tersebut disusun instrument untuk memperoleh data primer.

\section{Pengintegrasian Servqual Dimensi Pariwisata dengan QFD}

Penggabungan model servqual dimensi pariwisata dengan QFD ini dikarenakan untuk mempertajam analisis terkait dengan objek analisis adalah kualitas pada penyedia jasa objek wisata. Melalui HoQ dari QFD akan dapat dihubungkan antara atribut-atribut yang merupakan customer requirement serta respons teknikal organisasi. Integrasi antara dua model ini akan memberikan langkah sistematis dan operasional dalam perbaikan dan peningkatan kualitas atribut-atribut pada penelitian.

Gap 5 adalah kesenjangan antara jasa yang dirasakan dan jasa yang diharapkan. Apabila jasa yang diterima (persepsi) dan dirasakan sesuai dengan yang diharapkan (ekspektasi) oleh pengunjung, kualitas jasa dipersepsikan baik dan memuaskan. Sebaliknya, jika jasa yang diterima lebih rendah dibandingkan dengan yang diharapkan, maka kualitas jasa dipersepsikan buruk. Hal ini akan menyebabkan ketidakpuasan pengunjung objek wisata. Baik dan buruknya kualitas jasa objek wisata tergantung pada kemampuan penyedia jasa memenuhi harapan pengunjung.

Tabel 3 Kisi-Kisi Variabel Penelitian

\begin{tabular}{|c|l|l|l|c|}
\hline No. & \multicolumn{1}{|c|}{ Dimensi } & \multicolumn{1}{|c|}{ Keterangan } & Variabel Penelitian & Jumlah \\
\hline 1 & Atraksi & $\begin{array}{l}\text { Wahana permainan dan } \\
\text { pemandangan }\end{array}$ & $1,2,3,4,5,6,7,8$ & 8 \\
\hline 2 & Fasilitas & $\begin{array}{l}\text { Fasilitas yang disediakan } \\
\text { di objek lokasi }\end{array}$ & $9,10,11,12,13,14$ & 6 \\
\hline 3 & $\begin{array}{l}\text { Infrastructure \& } \\
\text { Transportation }\end{array}$ & Prasarana akses ke lokasi & $15,16,17,18,19,20$ & 6 \\
\hline 4 & Hospitality & $\begin{array}{l}\text { Credibility, courtesy, } \\
\text { competence }\end{array}$ & $\begin{array}{l}21,22,23,24,25,26, \\
27,28,29,30,31,32\end{array}$ & 12 \\
\hline 5 & $\begin{array}{l}\text { Information \& } \\
\text { promotion }\end{array}$ & $\begin{array}{l}\text { Informasi dan promosi } \\
\text { objek wisata }\end{array}$ & $33,34,35,36$ & 4 \\
\hline 6 & Price & Harga produk \& jasa & $37,38,39,40$ & 4 \\
\hline 7 & Assurance & $\begin{array}{l}\text { Rasa aman yang } \\
\text { diberikan objek wisata }\end{array}$ & $41,42,43$ & 3 \\
\hline
\end{tabular}


Tabel 4 Gap Skor Masing-Masing Atribut

\begin{tabular}{|c|c|c|c|c|}
\hline No. & Atribut & Kinerja & Harapan & Gap \\
\hline 1 & Jumlah spot foto mencukupi & 3,28 & 4 & $-0,72$ \\
\hline 2 & Keberagaman jenis dan variasi wisata mencukupi & 3,33 & 4,28 & $-0,95$ \\
\hline 3 & Pemandangan indah & 3,67 & 4,56 & $-0,89$ \\
\hline 4 & Ketersediaan spot untuk segala jenis umur & 3,22 & 4,44 & $-1,22$ \\
\hline 5 & Spot wisata modern & 3,39 & 4,22 & $-0,83$ \\
\hline 6 & Kebersihan objek wisata & 2,94 & 4,67 & $-1,73$ \\
\hline 7 & Wahana bermain terawat & 2,94 & 4,39 & $-1,45$ \\
\hline 8 & Penampilan wisata menarik (dekoratif) & 3,33 & 4,22 & $-0,89$ \\
\hline 9 & Ketersediaan tempat sampah yang memadai & 2,83 & 4,44 & $-1,61$ \\
\hline 10 & Jumlah fasilitas umum memadai (kursi, gazebo, dll.) & 2,94 & 4,17 & $-1,23$ \\
\hline 11 & $\begin{array}{l}\text { Fasilitas lengkap (warung, toilet, musholah, tempat sampah, } \\
\text { tempat istirahat). }\end{array}$ & 3,33 & 4,67 & $-1,34$ \\
\hline 12 & Fasilitas yang disediakan bersih & 2,89 & 4,5 & $-1,61$ \\
\hline 13 & Fasilitas yang disediakan rapi & 3,06 & 4,22 & $-1,16$ \\
\hline 14 & Tempat parkir memadai & 3,28 & 3,11 & 0,17 \\
\hline 15 & Ketersediaan transportasi yang mudah & 3,11 & 4,22 & $-1,11$ \\
\hline 16 & Kemudahan dalam menuju lokasi & 3,22 & 4,56 & $-1,34$ \\
\hline 17 & Ketersediaan (Kemudahan) sarana komunikasi & 3,11 & 4,44 & $-1,33$ \\
\hline 18 & Kemudahan dalam menghubungi pengelola & 2,83 & 4,39 & $-1,56$ \\
\hline 19 & Kemudahan dalam menghubungi petugas parkir & 3,11 & 4,28 & $-1,17$ \\
\hline 20 & Kemudahan dalam menghubungi petugas keamanan & 3,17 & 4,61 & $-1,44$ \\
\hline 21 & Tanggung jawab yang dimiliki pengelola & 3,06 & 4,44 & $-1,38$ \\
\hline 22 & Tanggung jawab yang dimiliki petugas parkir & 3 & 4,39 & $-1,39$ \\
\hline 23 & Tanggung jawab yang dimiliki pengelola rumah makan & 3,33 & 4,22 & $-0,89$ \\
\hline 24 & Kesopanan yang dimiliki pengelola & 3,29 & 4,33 & $-1,04$ \\
\hline 25 & Kesopanan yang dimiliki petugas parkir & 3,22 & 4,17 & $-0,95$ \\
\hline 26 & Kesopanan yang dimiliki pengelola rumah makan & 3,39 & 4,17 & $-0,78$ \\
\hline 27 & Kerapian yang dimiliki pengelola & 3,11 & 4,17 & $-1,06$ \\
\hline 28 & Kerapian yang dimiliki petugas parkir & 2,89 & 4,06 & $-1,17$ \\
\hline 29 & Kerapian yang dimiliki pengelola rumah makan & 3,06 & 4,28 & $-1,22$ \\
\hline 30 & Kesigapan yang dimiliki pengelola & 3,11 & 4,44 & $-1,33$ \\
\hline 31 & Kesigapan yang dimiliki petugas parkir & 3,33 & 4,28 & $-0,95$ \\
\hline 32 & Kesigapan yang dimiliki pengelola rumah makan & 3,33 & 4,39 & $-1,06$ \\
\hline 33 & Papan petunjuk wisata jelas & 3,39 & 4,33 & $-0,94$ \\
\hline 34 & Ketersediaan pusat informasi untuk pengunjung & 3,33 & 4,39 & $-1,06$ \\
\hline 35 & Kemudahan mendapatkan informasi mengenai tempat wisata & 3,39 & 4,44 & $-1,05$ \\
\hline 36 & Kegiatan promosi yang dilakukan menarik & 2,94 & 4,33 & $-1,39$ \\
\hline 37 & Harga tiket masuk terjangkau & 3,17 & 4,28 & $-1,11$ \\
\hline 38 & Harga makanan/minuman terjangkau & 3,06 & 4,22 & $-1,16$ \\
\hline 39 & Harga wahana terjangkau & 3 & 4,06 & $-1,06$ \\
\hline 40 & harga produk selain makanan/souvenir terjangkau & 3,06 & 4,17 & $-1,11$ \\
\hline 41 & Terjaminnya keamanan pengunjung beserta barang bawaannya & 3,06 & 4,44 & $-1,38$ \\
\hline 42 & Terjaminnya keamanan pengunjung dalam menggunakan wahana & 3,22 & 4,44 & $-1,22$ \\
\hline 43 & Terjaminnya keamanan kendaraan di tempat parkir & 3,56 & 4,44 & $-0,88$ \\
\hline
\end{tabular}


Kabul Trifiyanto, Ika Susilowati, Implementasi Metode Quality Function Deployment dan Metode Servqual Dimensi Kepariwisataan Guna Perbaikan Kualitas Pariwisata Pantai Kebumen

Secara garis besar langkah-langkah yang dilakukan dalam penelitian ini adalah sebagai berikut.

1. Analisis penilaian kualitas jasa untuk Gap 5.

2. Pembuatan model QFD

a. Penentuan respons teknis (house of quality)

b. Penentuan matriks hubungan antara respons teknis dengan kebutuhan konsumen

c. Benchmarking

d. Penentuan target

\section{ANALISIS DAN PEMBAHASAN}

\section{Analisis penilaian Kualitas Jasa untuk Gap 5}

Tahapan pertama adalah membandingkan penilaian dari jasa yang dirasakan (persepsi) dengan yang diharapkan (ekspektasi). Jika persepsi lebih tinggi dengan ekspektasi maka akan menghasilkan kepuasan namun jika gap yang terjadi adalah ekspektasi lebih tinggi dari persepsi maka kualitas dari jasa tersebut dapat dikatakan tidak memuaskan atau kualitasnya kurang baik.

Gap skor untuk masing-masing atribut dapat dilihat pada Tabel 4. Dari hasil perhitungan gap maka dapat disimpulkan bahwa nilai Servqual dari tujuh dimensi adalah negatif, dengan nilai gap terbesar terdapat pada atribut attraction/ wahana. Oleh karena itu, dapat disimpulkan bahwa kualitas pelayanan jasa di pariwisata pantai Kebumen masih kurang memuaskan.

\section{Quality Function Deployment}

Metode ini akan mempertemukan customer needs dengan respons teknis. Sebelumnya dari semua atribut yang ditanyakan ke responden tidak semuanya butuh perbaikan. Hanya atribut yang mempunyai pengaruh terbesar untuk ke- puasan konsumen yang akan dijadikan prioritas perbaikan. Penentuan prioritas ini diadaptasi dari Noriaki Kano (1984) yang mengembangkan model untuk mengategorikan atribut dari suatu produk atau layanan berdasarkan kemampuan atribut memenuhi kepuasan pelanggan. Kategori tersebut adalah sebagai berikut.

a. Basic needs yaitu kebutuhan dasar, artinya jika diberikan kualitas produk dengan layanan baik maka pelanggan akan merasa puas dan sebaliknya.

b. The dimensional yaitu kebutuhan yang bersifat linear, artinya jika pelanggan diberikan pelayanan baik akan puas dan jika diberikan pelayanan yang buruk akan kecewa.

c. The attractive yaitu kebutuhan ini bersifat laten, artinya pelanggan mungkin tidak memerlukan bahkan mungkin tidak berpikir untuk mendapatkannya namun bila diberikan akan senang.

Penentuan kebutuhan prioritas pengunjung dapat dilakukan dengan cara menggabungkan antara tabel servqual dengan gap minus dengan kategori nilai tertinggi "O" dan " $\mathrm{A}$ " dan " $\mathrm{M}$ ". Dari penggabungan tersebut maka didapatkan atribut prioritas yang dapat dilihat pada tabel daftar kebutuhan pengunjung. Untuk memudahkan pembacaan dalam QFD, prioritas kebutuhan konsumen diurutkan mulai dari nilai yang terbesar sampai ke nilai yang terkecil.

\section{Penentuan Respons Teknis}

Respons teknis merupakan tanggapan dari pihak perusahaan terhadap customer needs atau kebutuhan pengunjung. Respons untuk memenuhi kebutuhan pengunjung ada 16 hal yang dirinci pada tabel daftar matrix kebutuhan 
Tabel 5 Daftar Kebutuhan Pengunjung

\begin{tabular}{|c|l|c|c|c|c|}
\hline No. & \multicolumn{1}{|c|}{ Atribut } & Gap Skor & Kategori & Bobot & $\begin{array}{c}\text { Imp. } \\
\text { Level }\end{array}$ \\
\hline 3 & Pemandangan indah & 0,89 & A & 4 & 3,56 \\
\hline 6 & Kebersihan objek wisata & 1,73 & O & 2 & 3,46 \\
\hline 43 & $\begin{array}{l}\text { Terjaminnya keamanan kendaraan di tempat } \\
\text { parkir }\end{array}$ & 0,88 & O & 2 & 1,76 \\
\hline 9 & Ketersediaan tempat sampah yang memadai & 1,61 & O & 2 & 3,22 \\
\hline 37 & Harga tiket masuk terjangkau & 1,11 & O & 2 & 2,22 \\
\hline 12 & Fasilitas yang disediakan bersih & 1,61 & O & 2 & 3,22 \\
\hline 7 & Wahana bermain terawat & 1,45 & O & 2 & 2,9 \\
\hline 39 & Harga wahana terjangkau & 1,06 & O & 2 & 2,12 \\
\hline 42 & Terjaminnya keamanan pengunjung dalam & 1,22 & O & 2 & 2,44 \\
\hline 38 & Harga makanan/minuman terjangkau & 1,16 & O & 2 & 2,32 \\
\hline 21 & Tanggung jawab yang dimiliki pengelola & 1,38 & O & 2 & 2,76 \\
\hline 41 & $\begin{array}{l}\text { Terjaminnya keamanan pengunjung beserta } \\
\text { barang bawaannya }\end{array}$ & 1,38 & O & 2 & 2,76 \\
\hline
\end{tabular}

Tabel 6 Daftar Matrix Kebutuhan Hubungan Respons Teknis dengan Kebutuhan Konsumen

\begin{tabular}{|c|l|c|l|}
\hline 1 & $\begin{array}{l}\text { Memperbanyak spot gardu pandang dan menggali spot-spot } \\
\text { pemandangan baru }\end{array}$ & 3 & tahun \\
\hline 2 & Pembangun spot pemandangan buatan & 3 & buah \\
\hline 3 & $\begin{array}{l}\text { Menyediakan tempat sampah yang seragam dan membangun } \\
\text { sistem pengelolaan sampah serta membuat rambu-rambu } \\
\text { peringatan kebersihan }\end{array}$ & $6,9,12$ & buah \\
\hline 4 & Menstandarkan SOP serta instruksi kerja pelayanan & $6,9,12$ & subjek \\
\hline 5 & Menambah petugas kebersihan & $6,9,12$ & orang \\
\hline 6 & Memperluas lahan parkir & 43 & ha \\
\hline 7 & $\begin{array}{l}\text { Petugas parkir dipekerjakan secara resmi dan menggunakan } \\
\text { seragam serta tempat khusus dan perbaikan SOP }\end{array}$ & 43,41 & subjek \\
\hline 8 & Pemberlakuan harga tiket masuk di bundling dengan parkir & 37 & rupiah \\
\hline 9 & Penataan ulang lahan parkir & 43,41 & subjek \\
\hline 10 & $\begin{array}{l}\text { Membuat peraturan perawatan wahana secara rutin dan iuran } \\
\text { rutin untuk perbaikan yang ditarik dari pengelola wahana }\end{array}$ & 7,42 & subjek \\
\hline 11 & $\begin{array}{l}\text { Memberlakukan range harga standar dan memberikan } \\
\text { sosialisasi pada para pengelola rumah makan dan membuat } \\
\text { koperasi khusus pedagang }\end{array}$ & 38 & subjek \\
\hline 12 & Membangun call center atau pusat informasi & 21,41 & hari \\
\hline 13 & Menyediakan penitipan barang & 21,41 & hari \\
\hline 14 & Penyediaan P3K & 21,42 & buah \\
\hline 15 & Penyediaan speaker & 21 & buah \\
\hline 16 & Studi kelayakan objek wisata baru sekitar objek yang lama & 3 & subjek \\
\hline
\end{tabular}


Kabul Trifiyanto, Ika Susilowati, Implementasi Metode Quality Function Deployment dan Metode Servqual Dimensi Kepariwisataan Guna Perbaikan Kualitas Pariwisata Pantai Kebumen

hubungan respons teknis dengan kebutuhan konsumen.

\section{Penentuan Matriks Hubungan antara Respons Teknis dengan Kebutuhan Pengunjung}

Matrix hubungan antara kebutuhan pengunjung dengan respons teknis dari hasil penelitian. Penyusunan ini digunakan metode prioritas matriks. Semakin banyak respons teknis yang banyak berhubungan dengan kebutuhan pengunjung. Sebelum menentukan hubungan antar-kebutuhan pengunjung dengan respons teknis, dibuat terlebih dahulu daftar matriks kebutuhan terkait respons teknis yang disusun sesuai kebutuhan pengunjung. Daftar matrix dapat dilihat pada tabel daftar matrix kebutuhan hubungan respons teknis dengan kebutuhan konsumen.

\section{Benchmarking}

Metode ini dilakukan untuk mengetahui kelebihan dan kekurangan konsep produk jika dibandingkan dengan produk pesaing. Dari metode ini diperoleh informasi tambahan untuk menyelesaikan masalah atau melakukan perbaikan. Benchmarking dilakukan dengan cara menyebarkan kuesioner kepada pengunjung wisata Pantai Wonosari Yogyakarta. Hasil perbandingan didapatkan tingkat kepuasan pengunjung lebih besar di Wonosari ketimbang di lima pantai Kebumen. Detail perbandingan dapat dilihat di Tabel 7.

\section{Penentuan target}

Target yang ingin dicapai pada respons teknis dapat dilihat detail pada tabel daftar target untuk respons teknis.

\section{Penentuan Korelasi Respons Teknis (Correla- tion)}

Hubungan yang mungkin terjadi dari matrix kebutuhan dan respons teknis bisa kuat, sedang, dan lemah. Hubungan ini digunakan

Tabel 7 Benchmarking Kualitas Pelayanan Berdasarkan Persepsi Pengunjung

\begin{tabular}{|c|c|c|c|c|c|c|}
\hline \multirow{2}{*}{ No. } & \multirow{2}{*}{ Atribut } & \multicolumn{5}{|c|}{ Persepsi Pengunjung } \\
\hline & & 1 & 2 & 3 & 4 & 5 \\
\hline 3 & Pemandangan indah & & & Q & $\mathrm{O}$ & \\
\hline 6 & Kebersihan objek wisata & & Q & & $\mathrm{O}$ & \\
\hline 7 & Harga tiket masuk terjangkau & & Q & & $\mathrm{O}$ & \\
\hline 9 & Terjaminnya keamanan kendaraan di tempat parkir & & $\bar{Q}$ & & $\mathrm{O}$ & \\
\hline 12 & Ketersediaan tempat sampah yang memadai & & $\mathrm{Q}$ & & $\mathrm{O}$ & \\
\hline 21 & Fasilitas yang disediakan bersih & & & $\mathrm{Q}$ & $\mathrm{O}$ & \\
\hline 37 & Harga makanan/minuman terjangkau & & & Q & $\mathrm{O}$ & \\
\hline 38 & $\begin{array}{l}\text { Terjaminnya keamanan pengunjung dalam } \\
\text { menggunakan wahana }\end{array}$ & & & Q & $\mathrm{O}$ & \\
\hline 39 & Tanggung jawab yang dimiliki pengelola & & & $\mathrm{Q}$ & $\mathrm{O}$ & \\
\hline 41 & Wahana bermain terawat & & & $\mathrm{Q}$ & $\mathrm{O}$ & \\
\hline 42 & Harga wahana terjangkau & & & $\mathrm{Q}$ & $\mathrm{O}$ & \\
\hline 43 & $\begin{array}{l}\text { Terjaminnya keamanan pengunjung beserta barang } \\
\text { bawaannya }\end{array}$ & & & $\bar{Q}$ & $\mathrm{O}$ & \\
\hline
\end{tabular}


untuk menentukan seberapa perbaikan matrix korelasi jika terdapat elemen yang dianggap kritis. Korelasi antara respons teknis dengan respons teknis lainnya serta respons teknis dengan kebutuhan pelanggan dalam house of quality dapat dilihat pada lampiran. Urutan langkah dalam pembuatan HOQ mengikuti panduan dari Cohen dalam Bambang (2010).

Hasil analisis dengan menggunakan QFD akan menghasilkan pengetahuan mengenai prioritas kebutuhan konsumen yang harus diperbaiki. Prioritas kebutuhan konsumen tersebut adalah sebagai berikut.

1. Pemandangan disuguhkan harus indah.

2. Kebersihan objek wisata yang terjaga.

3. Ketersediaan tempat sampah pada setiap lokasi yang mudah dilihat atau terjangkau.

4. Kebersihan fasilitas umum yang disediakan.

5. Wahana bermain terawat dengan baik.

6. Tanggung jawab pihak pengelola dalam menangani keluhan dalam pelayanan.

7. Ketersediaan jaminan keamanan bagi para pengunjung.

8. Ketersediaan fasilitas keamanan untuk barang bawaan.

9. Ketersediaan peralatan keamanan standar pada wahana bermain.

10. Ketersediaan petugas keamanan pada setiap wahana keamanan.

11. Kesigapan petugas operator wahana dalam memberikan pelayanan.

12. Harga makanan dan minuman yang terjangkau dan standar pada setiap outlet.

13. Terjangkaunya harga tiket masuk.

14. Patokan harga wahana yang terjangkau.

15. Fasilitas tempat parkir yang memadai dan terjaga.

16. Adanya petugas keamanan pada lokasi parkir.

17. Jaminan yang pasti pada kendaraan di lokasi parkir.
Dari analisis HOQ dapat diketahui prioritas respons teknis yang harus dilakukan dari prioritas pertama sampai terakhir. Berikut prioritas respons teknis yang harus dilakukan.

1. Memperbanyak spot gardu pandang dan menggali spot-spot pemandangan baru.

2. Pembangun spot pemandangan buatan.

3. Menyediakan tempat sampah yang seragam dan membangun sistem pengelolaan sampah serta membuat rambu-rambu peringatan kebersihan.

4. Menstandarkan SOP serta instruksi kerja pelayanan.

5. Menambah petugas kebersihan.

6. Memperluas lahan parkir.

7. Petugas parkir dipekerjakan secara resmi dan menggunakan seragam serta tempat khusus dan perbaikan SOP.

8. Pemberlakuan harga tiket masuk di-bundling dengan parkir.

9. Penataan ulang lahan parkir.

10. Membuat peraturan perawatan wahana secara rutin dan iuran rutin untuk perbaikan yang ditarik dari pengelola wahana.

11. Memberlakukan range harga standar dan memberikan sosialisasi pada para pengelola rumah makan dan membuat koperasi khusus pedagang.

12. Membangun call center atau pusat informasi untung menampung kebutuhan dan keluhan pelanggan.

13. Menyediakan penitipan barang untuk mengakomodasi kebutuhan pengunjung dalam penyimpanan barang bawaan.

14. Penyediaan peralatan pertolongan pertama pada kecelakaan (P3K) dan perlengkapan evakuasi korban saat emergency.

15. Penyediaan speaker/pengeras suara untuk kebutuhan pemberitahuan informasi dan imbauan. 
Kabul Trifiyanto, Ika Susilowati, Implementasi Metode Quality Function Deployment dan Metode Servqual Dimensi Kepariwisataan Guna Perbaikan Kualitas Pariwisata Pantai Kebumen

16. Studi kelayakan objek wisata baru sekitar objek yang lama untuk menggali lagi potensi objek wisata.

\section{KESIMPULAN DAN SARAN}

Dari analisis QFD didapat 12 variabel kritis yang merupakan kebutuhan konsumen (customer

Tabel 8 Daftar Target untuk Respons Teknis

\begin{tabular}{|c|c|c|}
\hline No. & Respons Teknis & Target \\
\hline 1 & $\begin{array}{l}\text { Memperbanyak spot gardu pandang dan } \\
\text { menggali spot-spot pemandangan baru }\end{array}$ & $\begin{array}{l}\text { Gardu pandang di setiap sudut yang memungkinkan } \\
\text { mendapat pemandangan dapat di bangun. Jika tidak } \\
\text { memungkinkan bisa mencari lagi pemandangan baru di } \\
\text { sekitar objek wisata. Waktu pelaksanaan enam bulan. }\end{array}$ \\
\hline 2 & Pembangun spot pemandangan buatan & $\begin{array}{l}\text { Membuat spot untuk foto mengikuti tren pariwisata } \\
\text { dengan spot selfie yang diperbanyak dan bersifat } \\
\text { temporari dan bombastis. Waktu pelaksanaan tiga bulan. }\end{array}$ \\
\hline 3 & $\begin{array}{l}\text { Menyediakan tempat sampah yang seragam } \\
\text { dan membangun sistem pengelolaan } \\
\text { sampah serta membuat rambu-rambu } \\
\text { peringatan kebersihan serta }\end{array}$ & $\begin{array}{l}\text { Menyediakan tempat sampah setiap } 20 \text { meter dan di } \\
\text { spot-spot yang banyak makanan atau tempat istirahat } \\
\text { dan membuat rambu kebersihan. Waktu pelaksanaan } \\
\text { satu bulan. }\end{array}$ \\
\hline 4 & $\begin{array}{l}\text { Menstandarkan SOP, serta instruksi kerja } \\
\text { pelayanan }\end{array}$ & $\begin{array}{l}\text { Semua sistem kerja untuk semua petugas yang } \\
\text { berhubungan dengan pelayanan dapat dibuat sop dan } \\
\text { ditempel. Waktu pelaksanaan empat bulan. }\end{array}$ \\
\hline 5 & Menambah petugas kebersihan & $\begin{array}{l}\text { Penambahan petugas kebersihan minimal dengan } \\
\text { perhitungan radius seratus meter satu petugas dengan } \\
\text { tiga shift per hari. Waktu pelaksanaan enam bulan. }\end{array}$ \\
\hline 6 & Memperluas lahan parkir & $\begin{array}{l}\text { Jika memungkinkan diperluas lahan parkir namun jika } \\
\text { tidak cukup dengan lahan parkir temporari jika } \\
\text { pengunjung penuh. Waktu pelaksanaan enam bulan. }\end{array}$ \\
\hline 7 & $\begin{array}{l}\text { Petugas parkir dipekerjakan secara resmi } \\
\text { dan menggunakan seragam serta tempat } \\
\text { khusus dan perbaikan SOP }\end{array}$ & $\begin{array}{l}\text { Pembuatan sop disesuaikan dengan kebutuhan dan } \\
\text { pengaturan kerapian seragam dll. Waktu pelaksanaan } \\
\text { dua bulan. }\end{array}$ \\
\hline 8 & $\begin{array}{l}\text { Pemberlakuan harga tiket masuk di- } \\
\text { bundling dengan parkir }\end{array}$ & $\begin{array}{l}\text { Dilakukan paket tiket agar bisa lebih mudah pembelian. } \\
\text { Waktu pelaksanaan satu bulan. }\end{array}$ \\
\hline 9 & Penataan ulang lahan parkir & $\begin{array}{l}\text { Menata ulang lahan parkir agar lebih rapi dan } \\
\text { terjangkau dari pengawasan petugas parkir. Waktu } \\
\text { pelaksanaan dua bulan. }\end{array}$ \\
\hline 10 & $\begin{array}{l}\text { Membuat peraturan perawatan wahana } \\
\text { secara rutin dan iuran rutin untuk } \\
\text { perbaikan yang ditarik dari pengelola } \\
\text { wahana }\end{array}$ & $\begin{array}{l}\text { Membuat peraturan resmi ditandatangani semua petugas } \\
\text { sebagai komitmen dan dijadikan aturan ditempel. } \\
\text { Pelaksanaan tiga bulan. }\end{array}$ \\
\hline 11 & $\begin{array}{l}\text { Memberlakukan range harga standar dan } \\
\text { memberikan sosialisasi pada para pengelola } \\
\text { rumah makan dan membuat koperasi } \\
\text { khusus pedagang }\end{array}$ & $\begin{array}{l}\text { Pemberian sosialisasi pada pedagang dan memberikan } \\
\text { selebaran standar dan pembuatan MoU. Waktu } \\
\text { pelaksanaan delapan bulan. }\end{array}$ \\
\hline 12 & $\begin{array}{l}\text { Membangun call center atau pusat } \\
\text { informasi }\end{array}$ & $\begin{array}{l}\text { Mendirikan pusat informasi dan pelayanan keluhan dan } \\
\text { kebutuhan lain dari pengunjung. Waktu pelaksanaan } \\
\text { delapan bulan. }\end{array}$ \\
\hline 13 & Menyediakan penitipan barang & $\begin{array}{l}\text { Pembangunan tempat penitipan barang dijadikan satu } \\
\text { dengan pusat informasi. Waktu pelaksanaan delapan } \\
\text { bulan. }\end{array}$ \\
\hline 14 & Penyediaan P3K & $\begin{array}{l}\text { Menyediakan P3K di spot-spot penjagaan petugas. } \\
\text { Waktu pelaksanaan satu bulan. }\end{array}$ \\
\hline 15 & Penyediaan speaker & $\begin{array}{l}\text { Menyediakan speaker yang bisa menjangkau minimal } \\
100 \text { meter di area wisata untuk kebutuhan } \\
\text { pengumuman. Waktu pelaksanaan dua bulan. }\end{array}$ \\
\hline 16 & $\begin{array}{l}\text { Studi kelayakan objek wisata baru sekitar } \\
\text { objek yang lama }\end{array}$ & $\begin{array}{l}\text { Melakukan studi lebih lanjut terkait pengembangan } \\
\text { objek wisata dari segi wahana dan nilai jual lain. Waktu } \\
\text { pelaksanaan satu tahun. }\end{array}$ \\
\hline
\end{tabular}


needs) untuk segera diberi perhatian khusus dalam perbaikan. Pada perencanaan perbaikan didapat 16 respons teknis yang bisa dilakukan. Dari hasil analisis tersebut didapatkan lima besar prioritas perbaikan, pertama adalah pembuatan standar operation procedure petugas pengelola wisata beserta instruksi kerja. Kedua adalah penambahan personel petugas kebersihan, ketiga adalah penambahan gardu pandang dengan spot perspektif yang berbeda, keempat penambahan tempat sampah pada area yang mudah dijangkau, dan kelima perawatan wahana bermain dilakukan secara periodik/rutin.

\section{ACKNOWLEDGE}

Penelitian ini merupakan penelitian yang didanai oleh Kementerian Riset, Teknologi, dan Pendidikan Tinggi Republik Indonesia dalam skema penelitian dosen pemula.

\section{DAFTAR RUJUKAN}

Aritonang, Lerbin R. 2005. Kepuasan Pelanggan, Pengukuran dan Penganalisisan dengan SPSS. Jakarta: Gramedia Pustaka Utama.

Badan Pusat Statistik. 2017. Kebumen dalam Angka 2016. Kebumen. BPS.

Bambang P., Sri H., Agus. 2010. Perbaikan Kualitas Layanan Jasa dengan Model Servqual Dimensi Kepariwisataan dan Metode Quality Function Deployment (Studi Kasus PT $X$ Tempat Wisata Wahana Permainan). Semarang: Undip.

Cohen, Lou. 1995. Quality Function Deployment: How to Make QFD Work for You. USA: Addison-Wesley.

Ghozali, Imam. 2011. Aplikasi analisis multivariate dengan program IBM SPSS 19.
Semarang: Badan penerbit Universitas Diponegoro.

Kotler, Philip, \& Amstrong, Gery. 2004. Principles of Marketing (Tenth Edition). New Jersey: Pearson Prentice Hall.

Meidy, Charly Lasut. 2004. Evaluasi Perkembangan Pasar Kepariwisataan Bunaken di Kota Manado Pada Masa Sebelum dan Sesudah Krisis Ekonomi. Tesis TPWK. Semarang: Undip.

Sugiama, A., Gima. 2011. Ecotourism: Pengembangan Pariwisata Konsep dan Aplikasinya di Indonesia. Yogyakarta: Guardiya Intimarta.

Suwantoro, Gamal. 2009. Dasar-Dasar Pariwisata. Yogyakarta: Andi Offset.

Tjiptono, Fandy. 2006. Pemasaran Jasa. Malang: Bayumedia Publishing.

Widiyanto, Ibnu. 2008. Pointers: Metodologi Penelitian. Semarang: BP Undip.

Wijaya, Tony. 2011. Manajemen Kualitas Jasa. Yogyakarta: PT Index.

Yamit, Zulian. 2010. Manajemen Kualitas Produk dan Jasa. Yogyakarta: Ekonesia.

https://www.indonesia-investments.com/id/bisnis/ industri-sektor/pariwisata/item6051? Diakses pada 21 Juni 2017.

http://setkab.go.id/tahun-2017-kita-genjot-sektorpariwisata/ diakses pada tanggal 21 Juni 2017.

https://bisnis.tempo.co/read/news/2017/06/17/ 090885282/pemerintah-daerah-banyuwangi-diminta-fokus-kembangkan-wisata diakses pada tanggal 21 Juni 2017.

http://www.kebumenkab.go.id/index.php/public/ page/index/19/visi-dan-misi diakses pada tanggal 2017.

http://bisnis.liputan6.com/read/2848011/produkdomestik-bruto-ri-tembus-rp-12406-triliun diakses tanggal 21 Juni 2017. 